\title{
O PLEA BARGAINING NO PACOTE ANTICRIME: VANTAGENS E DESAFIOS DA INTRODUÇÃO DO INSTITUTO NO SISTEMA JURÍDICO BRASILEIRO
}

\author{
THE PLEA BARGAINING IN THE ANTICRIME PROJECT: ADVANTAGES AND CHALLENGES OF \\ INTRODUCING THE INSTITUTE INTO THE BRAZILIAN LEGAL SYSTEM
}

\author{
Fábio Henrique Falcone Garcia* \\ Alexandre Jorge Carneiro da Cunha Filho**
}

\begin{abstract}
Resumo:
O presente ensaio trata do avanço da introdução do Plea Bargaining no nosso sistema jurídico, discorrendo sobre vantagens e desvantagens do instituto considerando os fins maiores da jurisdição, dentre os quais certamente não está o de conduzir pessoas inocentes a assumirem um crime que não cometeram.

Palavras-chave: Acordos. Processo penal. Eficiência. Plea Bargaining. Projeto anticrime.

Abstract:

The present essay deals with the progressive introduction of Plea Bargaining in our legal system, discussing advantages and disadvantages of the doctrine, considering the major purposes of the jurisdiction, among which certainly is not to lead innocent people to confess a crime that they did not commit.
\end{abstract}

Keywords: Agreements. Criminal procedure. Efficiency. Plea Bargaining. Anticrime project.

1. Introdução: notas gerais sobre o "pacote anticrime" no contexto de contradições na evolução do Direito Penal

O Direito Penal contemporâneo vive uma crise de identidade. Tradicionalmente vinculado à contenção do arbítrio político, o Direito Penal liberal propugnava a garantia de direitos "de defesa do indivíduo contra ingerências do Estado em sua liberdade pessoal e de propriedade" (SARLET, 2004, p. 180).

Esse direito servia à legitimação da política, ao permitir a disseminação da crença de que o arbítrio pode ser contido pela ideia de isonomia e do governo de leis. As garantias penais e processuais penais assumiram uma função legitimatória da dominação e se afinavam às teorias políticas liberais clássicas, que veem no Estado um

Doutor em Filosofia e Teoria Geral do Direito. Mestre em Direito Constitucional. Juiz de Direito em São Paulo. E-mail: fabiofalcone@hotmail.com; http://lattes.cnpq.br/3741136644960620.

** Doutor e Mestre em Direito do Estado. Juiz de Direito em São Paulo. E-mail: alexandre@alexandrecunhafilho. com.br; http://lattes.cnpq.br/5265590933558476. 
mal justificado pela necessidade de se evitar o caos derivado de um estado hobbesiano de natureza (SANTOS, 1994, p. 104-115; CARNEVALI RODRÍGUEZ, 2008).

Nesse sentido, para Hassemer (2003, p. 147), o Direito Penal clássico surge com a crítica ao Direito Natural e com a necessidade de assegurar a liberdade possível ante o risco de desagregação em um estado de natureza.

Após a Segunda Guerra Mundial, intensificou-se a identidade do Direito Penal com o garantismo, entendido como fórmula política em que as instituições são instrumentais a serviço de direitos individuais, o que pressupõe sujeição à estrita legalidade e observância de limites substanciais impostos por direitos fundamentais (PIETRO SANCHÍS, 2009, p. 377).

No Brasil, o contexto histórico de promulgação da Constituição Federal de 1988, signo da redemocratização, com positivação de muitos princípios garantistas e o fortalecimento da classe dos advogados, ${ }^{1}$ permitiu o crescimento de uma tendência garantista, que se refletiu em algumas alterações legislativas processuais e penais, como por exemplo, a promulgação da Lei n. 9.099/1995, com definição das infrações de menor potencial ofensivo e introdução de institutos despenalizadores; as Leis ns. 10.259/2001 e 11.313/2006, a ampliar o conceito de infração de menor potencial ofensivo; o julgamento, no STF, do HC n. 73.662/1996, ao afirmar que seria relativa a presunção de violência prevista pelo então art. 224 do Código Penal; as modificações do Código de Processo Penal (Leis ns. 11.690/2008; 11.619/2008; 11.719/2008 e 11.900/2009), destinadas a reforçar aspectos acusatórios do processo penal; a modificação do regime de decretação da prisão preventiva e introdução das medidas cautelares diversas da prisão pela Lei n. 12.403/2011, com revogação do art. 393 do CPP, que previa prisão processual em razão de sentença condenatória recorrível; a determinação, pelo Conselho Nacional de Justiça, de realização de audiências de custódia (Resolução CNJ n. 213/2015).

Algumas dessas modificações foram estimuladas por agências de fomento internacional. A reforma processual penal, por exemplo, esteve na pauta dos programas desenvolvimentistas do Banco Mundial, inserindo-se em um programa de diagnóstico de autoritarismo institucional do sistema de justiça de toda América Latina. ${ }^{2}$

Fenômeno presente, também, na Alemanha, como observou Hassemer (2007).

2 Nesse sentido, ver Banco Mundial (2004). Fazendo com que a justiça conte: medindo e aprimorando o desempenho do Judiciário no Brasil. Relatório n. 32789-BR, de 30 de dezembro de 2004. Disponível em: http://documents.worldbank.org/curated/pt/927921468769735592/pdf/327890PORTUGUE10Que0A0Ju stica0Conte.pdf. Acesso em: 24 out. 2017. Segundo Jorge Esquirol, esses programas de reforma fazem parte de um discurso deslegitimatório dos sistemas de justiça da América Latina, a que chama de discurso do direito fracassado. Para ele, prevalece a intenção de desprestigiar as instituições locais, favorecendo processos de reforma que, segundo o autor, procuram inserir esses países em um contexto de globalização econômica, notadamente a partir de uma avaliação do direito pela economia (ESQUIROL, 2011, p. 439503). 
Paralelamente, contudo, foi possível observar a consolidação de um movimento expansionista do Direito Penal, costumeiramente vinculado ao rótulo Law and Order, ${ }^{3}$ em alusão à política norte-americana de tolerância zero contra delitos criminais. ${ }^{4}$

São exemplos dessa tendência a Lei n. 8.072/1990; as Leis ns. 9.034/1995 e 12.850/2013, ao tratar de crimes praticados por organizações criminosas, com meios investigatórios mais incisivos, tais como a ação controlada, a infiltração de agentes e a colaboração premiada, e com previsão de acesso, pelos órgãos de investigação, a dados do investigado independentemente de autorização judicial (art. 15); a Lei n. 11.340/2006, destinada à redução da violência doméstica de gênero, com tipos penais mais gravosos; a Lei n. 12.015/2009, com o incremento das penas e das condições punitivas em crimes contra a liberdade sexual; ${ }^{5}$ a Lei n. 10.741/2003, com majoração da pena para abandono de incapaz quando a vítima for maior de 60 anos; a Lei n. 13.104/2015, com tipificação do feminicídio. Em todas essas hipóteses, o incremento da resposta penal é meio de política criminal vocacionado à redução da criminalidade, lastreado na crença de maior rigor da legislação como desincentivo ao cometimento de delitos.

Essa aparente bipolaridade vem sendo objeto de estudo por penalistas de diversas nacionalidades.

Hassemer opõe o Direito Penal "clássico", próprio das garantias de liberdade, a um direito penal "moderno", em que a) a proteção dos bens jurídicos passa de um critério negativo para positivo de criminalização, ou seja, o que seria antes um limite ao legislador é visto como um desafio para responder a demandas sociais; b) a prevenção dos bens jurídicos se torna paradigma penal dominante, especialmente no que tange aos delitos envolvendo tráfico de entorpecentes, criminalidade organizada e terrorismo; e c) uma orientação consequencialista domina a retórica estrutural do Direito Penal, que se convola em instrumento de sensibilização das pessoas, o que se apresenta notadamente nos ramos específicos da tutela do meio ambiente e do gênero feminino. Segundo esse autor, há uma tendência a transformar o Direito Penal, de ultima ratio para prima ratio, um soft law que tem como escopo direção (Steuerung) social.

Silva Sánches (2002, p. 177-189), por seu turno, advoga a impossibilidade de tratar o Direito Penal a partir de uma unidade principiológica. Para ele, tal ramo do Direito contém dois grandes blocos de ilícitos, aqueles a que se comina pena prisional e

Fala-se em "tempestade global da lei e ordem", movimento que acompanha a onda punitivista inaugurada pela política de Rudolf Giuliani, Prefeito da cidade de Nova Iorque na década de 1990 (WACQUANT, 2012, p. 7-20).

4 Silva Sánches (2002, p. 25) rechaça essa vinculação, embora reconheça o uso instrumental da referência, como meio de integração a um novo "consenso social" sobre "as virtudes do Direito Penal como instrumento de proteção dos cidadãos".

5 Na prática, a modificação legislativa eliminou o debate instituído pelo HC n. 73.662/96. 
os que se vinculam a outro gênero de sanções. Essa distinção poderia dar azo a um Direito Penal de "duas velocidades", em que se estabeleceria um sistema de garantias qualificadas para a imputação de penas privativas de liberdade, ao lado de um sistema com garantias flexibilizadas para dar conta às demandas de imputação e responsabilização abrangentes, próprias dos contemporâneos ilícitos transnacionais, notadamente econômicos.

Ainda, para dar resposta às situações de agudas agressões à ordem jurídica, Silva Sánches admite a possibilidade restrita de um Direito Penal em que a privação da liberdade admitiria observância de regras de imputação e processuais "menos estritas que as do Direito Penal da primeira velocidade", "em alguns âmbitos excepcionais, e por tempo limitado" (SILVA SÁNCHES, 2002, p. 193-194). Esse Direito Penal de "terceira velocidade" seria a resposta de Silva Sánches àquilo que Jakobs tratou como Direito Penal do inimigo.

Jakobs (2007, p. 42) defende que o crime pode significar tanto o desvio de um cidadão que, como tal, se sujeita ao Estado de Direito e às suas garantias formais e materiais, como uma prática destinada à destruição do próprio ordenamento jurídico, caso em que o Estado estaria autorizado a reagir contra o "inimigo", utilizando-se de meios coativos mais severos. As garantias individuais do acusado poderiam ser mitigadas face ao risco que as próprias garantias poderiam representar ao Estado de Direito (JAKOBS, 2009, p. 33-34).

Em comum a essas análises, vê-se a incapacidade política de o Estado lidar com uma tendência de expansão da criminalidade organizada em meio a um contexto histórico no qual o Estado, rivalizado, ${ }^{6}$ procura demonstrar sua força por meio do incremento da dimensão simbólica de sua capacidade de fazer uso da violência institucionalizada, ao mesmo tempo em que este permanece preso às bases racionais de um Direito Penal vinculado à tradição liberal. ${ }^{7}$ Essas teorias procuram conferir um aporte teórico racional a tendências díspares do Direito Penal, que, em última análise, legitimase, em sua vertente "flexibilizada", pelo resultado da violência aplicada.

Essas soluções deixam transparecer um problema de identidade do Direito Penal, inerente ao deslocamento de sua função. Enquanto o Direito Penal "clássico" servia à legitimação do Estado de Direito por defender a liberdade e a isonomia jurídicas em sua expressão mais aguda, representando a limitação que o Direito impõe ao arbítrio estatal, o Direito Penal da modernidade tardia propugna um intervencionismo estatal na

Para usar expressão de Chevallier (2009, p. 48).

Sociologicamente, há um incremento da Gewalt, conceito que remete à capacidade de conjugação de convencimento e coerção, a partir da crença no poder incontrastável do Estado (COHN, 2017, p. 110). A incapacidade do Estado está relacionada a um plexo de fatores históricos, que sugerem a superação, como tipo ideal, do Estado providência a partir da emergência de um tipo de Estado de competição (FARIA, 2017, p. 139). 
orientação de uma sociedade de risco, com deslocamento da ênfase retributiva do Direito Penal clássico para um enaltecimento de seu caráter simbólico.

Essa discrepância produz um deficit de racionalidade do Direito Penal contemporâneo, já que as sucessivas modificações da lei penal pecam pela falta de um pensamento sistemático que confira unidade ao tratamento de situações. Assim, por exemplo, uma lesão leve envolvendo situação de violência doméstica passa a ter sua pena estipulada entre 3 meses e 3 anos, com escopo de evitar a aplicação das medidas despenalizadoras da Lei n. 9.099/1995.

Nesse contexto se insere o conjunto de propostas encaminhadas pelo Ministro Sérgio Moro ao Congresso Nacional, sob a rubrica genérica de "pacote anticrime". Uma análise perfunctória não permite antever no "pacote" uma cautela adequada à necessidade de sistematização ou ao tratamento do mencionado deficit de racionalidade do Direito Penal.

Embora concentrada em um único projeto de lei, as propostas não parecem formar um todo sistêmico, apresentando-se, antes, como um conjunto de soluções pontuais com escopo ora de recrudescimento da resposta punitiva estatal, ora de incremento da celeridade processual, com a intenção declarada de reduzir a sensação de impunidade.

A redação açodada de determinados dispositivos, como no caso da proposta referente à legítima defesa, ${ }^{8}$ e a inobservância de projetos de lei em curso, tais como o PL n. $8.045 / 2010^{9}$ e o PL n. $10.372 / 2018,{ }^{10}$ sugerem que o "pacote" serve mais de

8 O projeto introduz o parágrafo segundo ao art. 23 do $\mathrm{CP}$, assim redigido: “ $\$ 2^{\circ}$ O juiz poderá reduzir a pena até a metade ou deixar de aplicá-la se o excesso decorrer de escusável medo, surpresa ou violenta emoção". O que seriam medo, surpresa ou violenta emoção escusáveis? Sentimentos como medo, surpresa e emoção não são moralmente avaliáveis e, portanto, não são passíveis de avaliação moral. Logo, não são escusáveis nem inescusáveis. Para além da inadequação vernacular, o dispositivo, longe de aperfeiçoar a disposição da legítima defesa, introduz insegurança jurídica e aponta para uma dificuldade na apuração de excessos, em um contexto social de elevados índices de mortes provocadas por forças policiais e por grupos de extermínio. Ainda em relação à legítima defesa, o projeto prevê a introdução do parágrafo único ao art. 25, verbis: "Parágrafo único. Observados os requisitos do caput, considera-se em legítima defesa: I - o agente policial ou de segurança pública que, em conflito armado ou em risco iminente de conflito armado, previne injusta e iminente agressão a direito seu ou de outrem; e II - o agente policial ou de segurança pública que previne agressão ou risco de agressão a vítima mantida refém durante a prática de crimes". A redação, aqui, é redundante, perigosa e insegura, pois: a) a ação de policiais em conflitos armados, que repelem iminente e injusta agressão a direito seu ou de outrem está contida no caput do artigo; b) todavia, o caput faz referência ao uso moderado dos meios necessários, o que não é repetido no artigo; e c) essa omissão sugere a possibilidade de uma reação desproporcional, reforçada, de resto, pela redação desastrosa do parágrafo segundo do art. 23. Uma interpretação minimamente sistemática, contudo, importaria reconhecer a necessidade de uso moderado dos meios necessários em quaisquer situações. A imprecisão do texto projetado relegará, pois, para a jurisprudência a tarefa de compatibilizar os dispositivos.

9 Projeto de reforma do Código de Processo Penal. Disponível em: https://www.camara.leg.br/ proposicoesWeb/fichadetramitacao?idProposicao=490263. Acesso em: 26 fev. 2019.

10 Projeto de reforma da legislação penal e processual penal para aperfeiçoar combate ao crime organizado, apresentado pela comissão de juristas presidida pelo Ministro Alexandre de Morais. Disponível em: https:// 
instrumento suasório de legitimação do governo do que como um projeto de sistematização e racionalização da aplicação da lei penal.

Dito de outro modo, a falta de remissão a estudos empíricos ou mesmo de justificativa para as proposições enfraquece o texto apresentado como proposta legislativa parlamentar, embora aspire representar, aos olhos do público em geral, uma resposta célere à ânsia retributiva de uma sociedade aflita com os elevados índices de criminalidade violenta. ${ }^{11}$

Resta saber se, do ponto de vista jurídico-normativo, as modificações pontuais aventadas favorecem a redução das antinomias sistêmicas e, dessa forma, se viabilizam a construção de um sistema de persecução penal mais eficiente.

Nesse artigo, analisaremos as propostas de acordos para não persecução penal e assunção de culpa, reconhecidas, doutrinariamente, como a adoção entre nós do sistema da plea bargaining, de inspiração norte-americana.

\section{A figura do plea bargaining: origem e balanço do instituto na Common Law}

Por plea bargaining entende-se a possibilidade de concessões oficiais em troca da autoincriminação do acusado (ALSCHULER, 1979, p. 3), com a dispensa das formalidades inerentes ao julgamento de mérito decorrente de um processo penal regular. Teoricamente, propõe-se a flexibilização das formalidades inerentes à persecução penal em favor da redução de tempo e custos processuais, de um lado, e da perspectiva de redução ou substituição da pena privativa de liberdade, por outro.

$\mathrm{O}$ instituto se desenvolveu prioritariamente em países ligados à Common Law, notadamente no Reino Unido e Estados Unidos, onde se estima que entre 90\% a 95\% das condenações ocorram por meio do plea bargaining (DEVERS, 2011).

Alguns doutrinadores sugerem que o instituto sempre esteve presente na sistemática criminal da Common Law, em razão da discricionariedade que esses sistemas conferem aos órgãos acusatórios.

Essa noção é um pouco inexata, porque equipara formas embrionárias do instituto (como a dispensa da acusação por ato unilateral do acusador ou por troca de informações) com o condicionamento de benefícios em troca da autoincriminação, o que

www.camara.leg.br/propostas-legislativas/2178170. Acesso em: 26 fev. 2019.

11 Como se sabe, o Brasil vivencia uma crise de segurança pública sem precedentes. Em 2017 bastaram três semanas para que o número de homicídios do Brasil superasse o número de mortos em ataques terroristas ocorridos nos cinco primeiros meses no resto do mundo. De acordo com levantamento do Fórum Brasileiro de Segurança Pública, o volume de mortes no Brasil superou a situação da guerra da Síria, para igual período IPEA (2017, p. 55) e Anuário Brasileiro de Segurança Pública (2016, p. 20). Não por acaso, a segurança pública, cuja competência é atribuída aos Estados-membros da Federação pela CF/88, constituiu eixo central da campanha eleitoral do candidato vencedor, em 2018. 
suscitou dúvidas quanto à respectiva constitucionalidade (ALSCHULER, 1979, p. 4), ${ }^{12}$ que somente tardiamente veio a ser definida pela Suprema Corte norte-americana.

Alschuler propôs uma abordagem histórica, a partir da análise do posicionamento dos tribunais anglo-americanos em relação à assunção de culpa. De acordo com esse autor, embora os primeiros tratados reconhecidos da Common Law previssem a confissão (datados de 1189, 1250 e 1290), a maioria dos julgados até o final do século XIX indicavam uma desconfiança das cortes em relação à sua validade. Os juízes orientavam os acusados a retirar a confissão. Da mesma forma, consta de registros doutrinários antigos a vinculação da validade da confissão a um grau de espontaneidade, sem a qual a prova teria de ser descartada. Alguns julgados consideravam, por exemplo, a promessa de leniência como causa de invalidação de confissão extrajudicial (ALSCHULER, 1979, p. 7-16).

Ainda assim, a praticidade inerente à condenação em razão da confissão permitiu que esse tipo de acordo ganhasse corpo na prática judiciária. Ao final do século XIX, as condenações lastreadas em confissão cresceram exponencialmente (ALSCHULER, 1979, p. 18), ${ }^{13}$ indicando a existência de acordos informais de leniência entre acusação e acusado. Na década de 1920, vários Estados norte-americanos conduziram pesquisas sobre a justiça criminal, identificando percentuais sobrelevados de condenações lastreadas em confissões, a despeito da existência de uma cultura acadêmica de desconfiança em relação à assunção de culpa (plea guilty).

Essas pesquisas revelaram, também, que percentuais significativos dos condenados recebiam condenações menos severas do que as acusações iniciais, tornando possível a identificação do prêmio que a acusação oferecia em troca da dispensa do direito ao julgamento. Como consequência, o acordo tornava-se substancialmente vantajoso ao acusado em relação à possibilidade de condenação em um julgamento de mérito. ${ }^{14}$

Embora o instituto seja visto com reservas pela comunidade acadêmica, a Suprema Corte norte-americana, em 1970, acabou por chancelar sua constitucionalidade, lastreando-se em argumentos relacionados à liberdade do acusado e aos benefícios de um

12 Confira-se, ainda, o texto da $5^{\mathrm{a}}$ Emenda à Constituição dos Estados Unidos: "No person shall be held to answer for a capital, or otherwise infamous crime, unless on a presentment or indictment of a grand jury, except in cases arising in the land or naval forces, or in the militia, when in actual service in time of war or public danger; nor shall any person be subject for the same offense to be twice put in jeopardy of life or limb; nor shall be compelled in any criminal case to be a witness against himself, nor be deprived of life, liberty, or property, without due process of law; nor shall private property be taken for public use, without just compensation" (Grifo nosso).

13 De 1839 a 1926, os índices de condenação lastreados em guilty plea nos condados de Manhattan e Brooklyn subiram de $15 \%$ para $90 \%$.

14 Em 1917, um acusado da Virgínia que confessasse, renunciando ao julgamento, tinha 2,3 vezes mais chances de receber uma suspensão da pena do que um acusado que fosse condenado em julgamento; em 1927, discrepância atingia 6,3 vezes (ALSCHULER, 1979, p. 29). Ainda nesse sentido, ver: Gifford (1983, p. 39). 
acordo processual penal para aplicação de uma pena consensual. No paradigmático caso Brady vs. United States, a Corte afirmou a constitucionalidade do plea bargaining, desde que a confissão fosse espontânea.

Becker Jr. (1998, p. 759-761) recorda, todavia, que o julgamento não definiu quais os termos dessa "espontaneidade", dando azo a uma insegurança jurídica que se refletiu nas decisões ulteriores da própria Suprema Corte.

Em uma análise criteriosa sobre os posicionamentos da Suprema Corte acerca da validade das confissões em face da Quinta Emenda, Becker Jr. (1998, p. 781783 ) aponta para a imprecisão do conceito, que remete a uma situação ideal de mínima pressão em relação à confissão. De acordo com Sheppard (1981, p. 168-169), a Suprema Corte é acusada de conferir lastro a uma prática fundada em um inexistente equilíbrio entre as partes em negociação, já que a premissa de que os acordos são justos pode não se verificar em casos concretos.

No mesmo sentido, é a crítica de Gifford (1983, p. 39), para quem a Suprema Corte errou, ao equiparar uma situação de equilíbrio (acordo consensual em uma demanda cível) com a situação do acusado perante o órgão acusatório, em que aquele é praticamente coagido a confessar para evitar o risco de condenações mais severas.

Argumenta-se, em favor do plea bargaining, que o sistema pressupõe um equilíbrio de forças entre a acusação - que não teria a certeza da condenação - e a defesa, em um exercício prognóstico acerca das possibilidades de julgamento. Nesse caso, a medida atenderia ao interesse de todos, já que inocentes não aceitariam o acordo; e prováveis culpados poderiam reduzir a perspectiva de pena, poupando custos processuais, ao passo que a acusação se livraria da necessidade de demonstrar, de forma cabal, a imputação. Com isso, presumíveis culpados seriam responsabilizados, ainda que de forma menos severa do que a prevista em lei, reduzindo-se o risco de impunidade. De acordo com uma pesquisa empírica com profissionais que trabalhavam com plea bargaining na década de 1970, promotores de acusação acreditam que o acordo em si não incrementa o risco de condenação de inocentes, porque essas pessoas não seriam susceptíveis às pressões.

O cálculo de custo-benefício, contudo, serve igualmente de argumento contrário ao instituto. Observações empíricas sugerem que o promotor de acusação, administrando o poder de oferecer o acordo, realiza acusações intencionalmente mais gravosas com o escopo de forçar a aceitação do ajuste (GIFFORD, 1983, p. 43; ALSCHULER, 1979, p. 40). Constatou-se, ainda, que os benefícios ofertados costumam ser maiores nas situações em que a prova é mais fraca, a indicar que o cálculo de custobenefício inclui a condenação de possíveis inocentes, ante o estímulo provocado pelas condições altamente benéficas (SHEPPARD, 1981, p. 169-170).

A partir dessas observações, critica-se a consistência do modelo, já que coloca inocentes e culpados em uma situação de indistinção perante a oferta de acordo, 
facilitando a condenação de inocentes e a aplicação de penas brandas a culpados. Ainda, privilegia a condição dos culpados em detrimento da situação de inocentes, que são compelidos ora a aceitar acordos pouco satisfatórios, em razão do risco eventual de condenação, ora a aceitar o risco processual, com imputações originalmente mais severas, porque maximizadas para estimular a negociação. ${ }^{15}$ Finalmente, sustenta-se a inexistência de equilíbrio entre as partes, já que o acusado não possui o conjunto de informações que está na posse do acusador, a despeito da garantia de acesso às provas da parte contrária. ${ }^{16}$

De modo geral, pois, entende-se que o instituto conseguiu tamanha proeminência em razão de sua conveniência à administração da justiça, representando antes uma necessidade de equacionamento econômico dos custos da persecução penal em função da eficiência almejada para o sistema, conforme reconhecido pelos tribunais norteamericanos (SHEPPARD, 1981, p. 168, nota 25). Há certo consenso em reconhecer que o instituto traz eficiência no preciso sentido de incrementar celeridade à resposta punitiva estatal, com redução significativa dos custos procedimentais.

A crítica, por outro lado, se concentra sobre a injustiça do modelo, que favoreceria a concessão de benefícios a pessoas culpadas e, por outro lado, a condenação de inocentes, como resultado de uma política pública de segurança pautada na manutenção de elevadas taxas de condenação.

\section{Processo como meio para satisfação das finalidades públicas}

O processo judicial não é um fim em si mesmo, mas um meio dirigido ao bom exercício da função jurisdicional. ${ }^{17}$

A previsão de um rito a ser seguido como condição para o desenvolvimento legítimo da competência estatal de dizer o Direito no caso concreto serve tanto a finalidades públicas como privadas.

Se por um lado a forma garante o indivíduo contra o exercício abusivo do Poder, por outro lado ela preordena os atos da autoridade estatal rumo ao desempenho eficiente da tarefa que lhe incumbe.

15 A doutrina chama esse tipo de argumento crítico ao Plea Bargaining de problema da inocência. Para uma abordagem relativamente recente acerca dessa questão, com apoio de um estudo empírico realizado com estudantes, ver: Dervan e Edkins (2013).

16 Isso porque, no sistema norte-americano, a exposição das provas à parte contrária é informal, conforme salienta Sheppard (1981, p. 174).

17 Dados os limites estreitos deste ensaio, nos limitaremos a falar sobre as finalidades do processo judicial. Nada obstante, importante observar que o "processo" é um instituto da Teoria Geral do Direito, encontrando aplicação onde quer que se tenha exercício de Poder, o que se dá no âmbito tanto de órgãos judiciários como nos executivos e legislativos. Sobre o ponto, por todos, ver Medauar (2008, p. 18 et seq.). 
Não há, ou aos menos não deveria haver, incompatibilidade entre os dois valores indicados.

A jurisdição eficiente é a que observa o direito individual ao contraditório e à ampla defesa, pronunciando, em um prazo razoável, o entendimento do Estado-juiz quanto à pretensão que lhe fora apresentada por um postulante em face de outro.

Tal pronunciamento, nada obstante a constante pressão sobre o nosso aparato de Justiça no que se refere à produção de números cada vez mais expressivos em um mesmo espaço de tempo, não é um afirmar qualquer.

O juiz, ao dizer o Direito em uma disputa que é submetida à sua apreciação, não se limita a oferecer uma resposta possível segundo os textos normativos vigentes em nosso sistema.

A partir de um ato de conhecimento e de valoração de fatos que reclamam a aplicação de leis, ${ }^{18}$ o julgador procede a um juízo hermenêutico que, segundo sua avaliação, é o mais adequado para a situação litigiosa, conforme um sentimento de Justiça ${ }^{19}$ partilhado entre os membros de uma comunidade.

O processo, pois, é o caminho para que se dê tal operação mental que, longe de ser indiferente aos seus efeitos na realidade, ${ }^{20}$ encontra seu fundamento de legitimidade justamente em sua utilidade para assegurar a convivência harmônica entre os indivíduos, ou seja, em sua capacidade de dirimir controvérsias, contribuindo para pacificação social.

3.1. Processo criminal como meio para satisfação das finalidades do Direito Penal prevenção geral, especial e ressocialização

O processo penal é aquele por meio do qual o Estado-juiz avalia a veracidade da imputação de um delito que é feita pelo Estado-acusador (Ministério Público) a um indivíduo, conforme uma denúncia que ofereça ao menos prova de materialidade do ilícito (violação a uma norma penal) e indícios suficientes de que o réu é o respectivo responsável.

\footnotetext{
Nossa compreensão do fenômeno é inspirada em lições como a de Eros Grau (2002).

Sobre o tema ver a Johnston (2018).

20 O que entre nós inclusive ganhou referência expressa em nossa legislação com a inserção na Lei de Introdução às Normas do Direito Brasileiro do art. 20, caput, feito pela Lei n. 13.655/2018: "Nas esferas administrativa, controladora e judicial, não se decidirá com base em valores jurídicos abstratos sem que sejam consideradas as consequências práticas da decisão". Disponível em: http://www.planalto.gov.br/ ccivil_03/decreto-lei/Del4657compilado.htm. Acesso em: 1 mar. 2019. Para comentários sobre o papel e possíveis aplicações do dispositivo em nosso ordenamento, ver Cunha Filho, Issa e Schwind (2019, v. 2, p. 63 et seq.).
} 
Ao fim do iter previsto para a análise dos fatos veiculados na acusação, ${ }^{21}$ deverá o julgador, caso inexistente, depois de encerrada a instrução, qualquer dúvida razoável acerca da autoria do crime, cominar uma pena ao infrator.

Tal sanção cumpre algumas funções em nosso sistema de Justiça, ${ }^{22}$ dentre as quais se destacam, a nosso ver, as de prevenção geral e especial, sendo desejado que após o procedimento em tela aquele reconhecido como culpado por um delito se reconcilie com a lei, admitindo a falta que fora demonstrada em juízo e sentindo-se desestimulado a reincidir na prática criminosa (ressocialização). ${ }^{23}$

Dessa forma, um processo penal vocacionado à absolvição do inocente e à penalização do culpado teria por fim precípuo a tutela dos bens jurídicos eleitos pelo legislador como dignos dessa grave proteção, oferecendo resposta em tempo razoável para os infratores (sanção), de modo a sinalizar tanto para estes quanto para população em geral que violações às regras de conduta tipificadas terão consequências sensíveis para os respectivos responsáveis.

Outro desdobramento de um processo penal eficiente nos termos referidos é a possibilidade de reparação do dano causado, efeito que, quando viável, ${ }^{24}$ permite desde logo a recomposição do prejuízo/ofensa suportado(a) pela vítima, sem que haja necessidade de esta propor uma ação de indenização na seara cível com tal objetivo (a não ser que pretenda uma reparação complementar).

Ou seja, após violado um bem jurídico resguardado pela lei penal, identificando-se o responsável pelo ilícito, como um dos reflexos de sua condenação está justamente a recuperação do valor afetado por sua conduta, o que, segundo nosso entendimento, não tem o mesmo propósito do instituto da sanção pecuniária (que, como pena, não teria caráter ressarcitório, mas sim de prevenção à prática de atos desconformes à lei).

21 Em que se observará, com a maior intensidade possível, as garantias do contraditório e da ampla defesa, haja vista a gravidade das consequências que podem advir deste processo para o acusado (ao qual pode ser imposta pena privativa de liberdade).

22 Sobre o ponto, ver Bitencourt (2002, p. 65 et seq.) e Prado (2014, p. 91 et seq.).

23 Outra função comumente referida para a pena é a retributiva, que poderia ser definida como a de atribuição de mal justo por um mal injusto (BITENCOURT, 2002, p. 69 et seq.). Não nos parece que tal função deva ser entendida de modo autônomo quando considerada a questão da prevenção que, a nosso ver, seria o principal propósito para a imposição de castigo para quem viole uma regra, ou seja, a preservação de bens jurídicos caros à sociedade pelo receio de consequências desfavoráveis a serem impostas ao respectivo infrator.

24 Em especial nos crimes cometidos contra o patrimônio (particular ou público), quando os respectivos agentes têm condições financeiras de realizar o ressarcimento. 
4. Compatibilidade do plea bargaining com os objetivos da jurisdição criminal

Para ser compatível com os objetivos da jurisdição criminal, qualquer concessão de vantagem ao acusado em troca da confissão pressupõe, justamente, que esta seja informada e espontânea, já que não interessa ao sistema de justiça a punição de pessoa que não tenha relação com o delito investigado.

Se a pena tem por propósito principal dissuadir os indivíduos quanto à prática de crimes, ou seja, quanto à violação de bens tutelados pela lei penal, não faz sentido algum se assumir o risco de impor gravame a um estranho aos fatos apurados, ainda que sob pretexto de uma maior economia de recursos representada pela dispensa do devido processo legal.

Em tese, permitir a um réu desde logo confessar o cometimento de uma infração e sujeitar-se a uma sanção, caso este, devidamente assessorado por seu advogado, entenda inconveniente se submeter a um processo no qual dificilmente se sagrará vencedor (o que pode ocorrer em casos de prisão em flagrante ou em que o delito é filmado, por exemplo), é medida que vai ao encontro da instrumentalidade do exercício do Poder, ${ }^{25}$ trazendo potenciais vantagens para todos os atores envolvidos na atividade persecutória (sobretudo ao acusado que, tendo sua autonomia preservada, ainda obterá benefícios diversos daqueles que o juiz poderia lhe conferir fora da sistemática do acordo).

Logo, partindo de tal premissa, mas sem desconsiderar as críticas que vem sendo feitas com relação a plea bargaining na Common Law, é preciso refletir sobre a melhor forma de o mecanismo ser implantado (ou melhor ampliado) em nosso país, inclusive levando em conta que algumas das hesitações expressadas pela doutrina norteamericana felizmente não se colocam, ou ao menos não com a mesma intensidade, no nosso sistema. ${ }^{26}$

A respeito, vale notar que atualmente muitos países da Civil Law têm assimilado formas similares de flexibilização da persecução penal, em condições muito distintas das que se observa na experiência norte-americana.

25 E na mesma direção da introdução progressiva de módulos convencionais de exercício do Poder também na função administrativa, sede em que vem ganhando força a ideia de satisfação de interesses públicos de modo mais eficiente pela via dialogada e contratualizada com o particular do que a do tradicional ato imperativo unilateral, o qual nem sempre é capaz, sem a voluntária adesão dos seus destinatários aos respectivos termos, de atingir as finalidades de utilidade coletiva a que se propõe. Sobre o ponto, confira-se: Palma (2015) e Marrara (2015).

26 Do que é exemplo a circunstância de os nossos juízes e promotores ingressarem em suas carreiras via concurso público e serem dotados de expressiva independência funcional, enquanto que nos Estados Unidos uma parte importante desses atores (em especial no âmbito da Justiça Estadual) é composta de membros eleitos pela população, o que implica risco da exploração eleitoral dos índices de condenação criminal obtidos em razão da atuação de tais profissionais. 
De acordo com Kishan (2018), cerca de 88\% das nações admitem alguma forma de plea bargaining. A França, por exemplo, sofreu uma reforma processual penal em 2004 e passou a admitir um modelo de plea bargaining um pouco mais restrito, limitado a crimes apenáveis com até 5 anos de prisão, admitindo-se a possibilidade de proposição de um acordo de pena prisional de até 1 ano (GIVATI, 2011, p. 2).

Em um quadro comparativo entre países da Common Law e da Civil Law que adotam o instituto e o grau de sua aplicabilidade, Givati sugere que a forma como este se opera depende de uma atenção maior ou menor para com duas variáveis, a saber: a) em sociedades mais preocupadas com a certeza da pena sobre culpados, a técnica tem tido maior aceitabilidade; b) em sociedades mais preocupadas com a possibilidade de erros judiciários (em especial no que concerne à punição de inocentes), o mecanismo encontra maior resistência. Observando outra variável empírica, Givati constata que quanto maior o índice de criminalidade, ${ }^{27}$ maior é a tendência de adoção do instituto nos diversos países pesquisados.

Essas considerações permitem que se observe a proposta de sua admissibilidade com alguma acuidade científica: como toda proposta legislativa que repercute na estrutura do processo acusatório penal, o plea bargaining afeta as condições de funcionamento do sistema de justiça, com resultados positivos e negativos.

Como foi possível argumentar na seção introdutória, o incremento das taxas de criminalidade e as transformações estruturais do Estado brasileiro apontam para um deslocamento das estruturas legitimatórias do Direito Penal, antes lastreado nos direitos e garantias individuais e agora voltado para a disseminação da dimensão simbólica da força estatal, em um contexto no qual os custos processuais e temporais são cada vez mais relevantes.

Por essa razão, soluções consensuais são estimuladas, o que não necessariamente implica algum tipo de inconstitucionalidade.

A Lei n. 9.099/1995, por exemplo, introduziu no ordenamento pátrio a figura da transação penal, que nada mais é do que um acordo de não persecução penal, em troca de penas não privativas de liberdade, para hipóteses de infrações de menor potencial ofensivo.

Longe de representar, portanto, uma mácula per se ao direito de defesa, a questão central acerca da compatibilidade, entre nós, do instituto do plea bargaining em relação aos valores constitucionalmente consagrados reside na forma pela qual se admitirá sua regulação.

27 Dado obtido a partir da análise dos números de homicídio, nos diversos países. 
Em princípio, portanto, cremos compatível com o texto constitucional a consensualidade proposta. E admitimos como razoável e salutar, do ponto de vista político-criminal, a introdução de condições de exercício da consensualidade no âmbito persecutório penal, desde que observadas algumas balizas a fim de assegurar a higidez do sistema de garantias constitucionais.

\subsection{Crítica ao texto projetado}

Embora a proposição de formas consensuais de solução da persecução penal seja uma ideia salutar, pelos motivos expostos, as propostas concretamente apresentadas no "Pacote Anticrime" merecem algumas críticas, porque, ao buscarem a importação de um instituto pouco regulado e muito criticado sem considerar as peculiaridades da cultura jurídica local, podem redundar tanto em ineficiência sob o ponto de vista políticoadministrativo da justiça, como em prejuízo ao direito de defesa, o que pode despertar questionamentos quanto à sua constitucionalidade.

Em relação ao acordo de não persecução penal, o projeto dispõe:

Art. 28-A. Não sendo o caso de arquivamento e tendo o investigado confessado circunstanciadamente a prática de infração penal, sem violência ou grave ameaça, e com pena máxima inferior a quatro anos, o Ministério Público poderá propor acordo de não persecução penal, desde que necessário e suficiente para a reprovação e prevenção do crime, mediante as seguintes condições, ajustadas cumulativa ou alternativamente: I - reparar o dano ou restituir a coisa à vítima, salvo impossibilidade de fazê-lo; II - renunciar voluntariamente a bens e direitos, indicados pelo Ministério Público como instrumentos, produto ou proveito do crime; III - prestar serviço à comunidade ou a entidades públicas por período correspondente à pena mínima cominada ao delito, diminuída de um a dois terços, em local a ser indicado pelo Ministério Público; IV - pagar prestação pecuniária, a ser estipulada nos termos do art. 45 do Código Penal, a entidade pública ou de interesse social a ser indicada pelo Ministério Público, devendo a prestação ser destinada preferencialmente àquelas entidades que tenham como função proteger bens jurídicos iguais ou semelhantes aos aparentemente lesados pelo delito; e V - cumprir, por prazo determinado, outra condição indicada pelo Ministério Público, desde que proporcional e compatível com a infração penal imputada. (...). § $2^{\circ}$ Não será admitida a proposta nos casos em que: I - for cabivel transação penal de competência dos Juizados Especiais Criminais, nos termos da lei; II - for o investigado reincidente ou se houver elementos probatórios que indiquem conduta 
criminal habitual, reiterada ou profissional, salvo se insignificantes as infrações penais pretéritas; III - ter sido $o$ agente beneficiado anteriormente, no prazo de cinco anos, em acordo de não persecução penal, transação penal ou suspensão condicional do processo; e IV - não indicarem os antecedentes, a conduta social e a personalidade do agente, bem como os motivos e as circunstâncias, ser necessária e suficiente a adoção da medida. (Grifo nosso).

A proposta parece reproduzir, em grande parte, os termos em que redigida a Resolução CNMP n. 181/2017, com a redação que lhe foi dada pela Resolução n. 183/2018, que permite, em condições bastante análogas, a formulação de acordo de não persecução penal pelo Ministério Público.

As distinções, porém, são significativas: enquanto na regulamentação atual se estabelece a possibilidade de formação de acordo em situações nas quais a pena mínima cominada (ou seja, imaginada em perspectiva concreta) seja de até quatro anos, pelo projeto de lei o ajuste encontraria limites tendo por parâmetro as penas máximas cominadas pela lei penal. Com isso, o instituto teria uma aplicabilidade significativamente mais restrita que a existente hoje em âmbito regulamentar, notadamente para situações envolvendo práticas delituosas frequentes no dia a dia forense, como furtos envolvendo qualquer espécie de qualificadora ou tráfico simples de entorpecentes.

Nesse sentido, se a intenção é viabilizar a maximização da eficácia punitiva penal para delitos não tão graves, sem os efeitos secundários deletérios da condenação para o acusado, o projeto se mostra tímido e quiçá ineficiente, já que exclui grande parte do espectro de tipos penais que, embora não acarretem encarceramento, são responsáveis pelo abarrotamento do sistema processual penal brasileiro. ${ }^{28}$

Além disso, a proposta padece de algumas cláusulas de cautela problemáticas. $\mathrm{O}$ acordo seria vedado nas hipóteses da presença de reincidência ou de "elementos probatórios que indiquem conduta criminal habitual (...), salvo se insignificantes as infrações penais pretéritas".

Embora seja razoável a vedação da concessão do acordo quando houver indícios de reiteração criminosa, ainda que outros fatos imputados ao acusado estejam pendentes de avaliação em sentença com trânsito em julgado, a expressão "conduta criminal habitual” carece de maior tecnicidade, é infeliz ao sugerir um juízo subjetivo

\footnotetext{
${ }_{28}$ Basta ver os dados do relatório do Departamento Penitenciário Nacional (2017), em que se identificam percentuais expressivos de presos aguardando julgamento, sem condenação, sendo significativas as imputações referentes a furto e tráfico de entorpecentes que, nas modalidades menos gravosas, ensejariam formulação de acordo de não persecução penal na forma hodiernamente regulamentada. Disponível em: http:// depen.gov.br/DEPEN/depen/sisdepen/infopen/relatorios-sinteticos/infopen-jun-2017-rev-12072019-0721. pdf. Acesso em: 27 fev. 2019.
} 
quanto à probabilidade de reincidência do agente como traço de sua personalidade e é redundante considerando o quanto previsto a respeito na Resolução CNMP n. 181/2017.

A insegurança é agravada pela possibilidade de se desconsiderar práticas infracionais pretéritas porque insignificantes sem que haja mínimos elementos a permitir uma definição normativa do conceito de insignificância.

Parece claro que o projeto não se refere, aqui, à interpretação doutrinária que exige efetiva lesão ao bem jurídico tutelado como condição de tipicidade penal (ZAFFARONI, 2018, p. 507), de modo que talvez bastasse a remissão expressa à reincidência, às circunstâncias do art. 59 do Código Penal ( $\$ 2^{\circ}$, inciso IV) e à cláusula geral de cautela do caput (desde que necessário e suficiente para a reprovação e prevenção do crime) como âmbito de discricionariedade do Ministério Público na avaliação da conveniência da oferta.

Sobre a desnecessidade da controversa estipulação, vale ainda ressaltar que a Resolução CNMP n. 181/2017 já prescreve que o acordo deve ser necessário e suficiente para reprovação e prevenção do crime, consoante análise do órgão acusatório. E, também, há previsão de aferição da conveniência do acordo em razão das chamadas circunstâncias judiciais, previstas pelo art. 59 do CP (inciso IV). Nesse sentido, parece que, normativamente, a proposta é menos cuidadosa do que a disciplina atualmente constante na regulamentação em tela, que, de resto, serviu de lastro ao Projeto de Lei n. $10.372 / 2018$.

Acerca das consequências do descumprimento do acordo que, à semelhança da transação, importa rescisão e oferecimento de denúncia, restando suspenso o prazo prescricional durante o período do respectivo cumprimento, a proposta se revelou tímida, já que se limitou a normatizar solução construída pela jurisprudência para violação do ajuste, quando se poderia avançar para o estabelecimento de uma hipótese de aplicação imediata de restrição de liberdade sem condenação como resposta ao rompimento do pacto, quiçá por curto espaço temporal e em estabelecimentos distintos dos presos comuns.

Do contrário, a redução de custos inerentes à adoção do acordo de não persecução penal seria atingida somente nas hipóteses de elevados índices de sua observância pelos agraciados.

Além disso, desde que a restrição da liberdade seja acompanhada de garantias específicas (estabelecimentos prisionais próprios, de segurança mínima, por relativo curto espaço de tempo), entendemos que a proposta não encontraria óbice em nossa ordem constitucional, já que, observando os direitos dos acusados, ainda atenderia aos reclamos da prevenção geral quanto ao cometimento de crimes, efeito que, como referido linhas acima, deveria ser a preocupação primeira do aparato sancionador estatal.

Para o acusado, assumindo-se a perspectiva de que o acordo é produto de uma negociação em que se analisam custos e benefícios, haveria a certeza da não condenação 
e de uma restrição de liberdade por tempo restrito. Por outro lado, o descumprimento importaria pronta e certa sanção, a desestimulá-lo.

Após oferecimento de denúncia e até o início da instrução, o projeto prevê a possibilidade de acordo para aplicação imediata de pena, sem, contudo, indicar limites à imputação penal.

Art. 395-A. Após o recebimento da denúncia ou da queixa e até o início da instrução, o Ministério Público ou o querelante e o acusado, assistido por seu defensor, poderão requerer mediante acordo penal a aplicação imediata das penas. $\S 1^{\circ}$ São requisitos do acordo de que trata o caput deste artigo: I - a confissão circunstanciada da prática da infração penal; II - o requerimento de que a pena privativa de liberdade seja aplicada dentro dos parâmetros legais e considerando as circunstâncias do caso penal, com a sugestão de penas em concreto ao juiz; e III - a expressa manifestação das partes no sentido de dispensar a produção de provas por elas indicadas e de renunciar ao direito de recurso. $\S 2^{\circ} \mathrm{As}$ penas poderão ser diminuídas em até a metade ou poderá ser alterado o regime de cumprimento das penas ou promovida a substituição da pena privativa por restritiva de direitos, segundo a gravidade do crime, as circunstâncias do caso e o grau de colaboração do acusado para a rápida solução do processo. $\S 3^{\circ}$ Se houver cominação de pena de multa, esta deverá constar do acordo. $\S 4^{\circ}$ Se houver produto ou proveito da infração identificado, ou bem de valor equivalente, a sua destinação deverá constar do acordo. $\S 5^{\circ}$ Se houver vítima decorrente da infração, o acordo deverá prever valor mínimo para a reparação dos danos por ela sofridos, sem prejuízo do direito da vítima de demandar indenização complementar no juízo cível. $\S 6^{\circ}$ Para homologação do acordo, será realizada audiência na qual o juiz deverá verificar a sua legalidade e voluntariedade, devendo, para este fim, ouvir o acusado na presença do seu defensor. $\S 7^{\circ}$ O juiz não homologará o acordo se a proposta de penas formulada pelas partes for manifestamente ilegal ou manifestamente desproporcional à infração ou se as provas existentes no processo forem manifestamente insuficientes para uma condenação criminal. $\S 8^{\circ}$ Para todos os efeitos, o acordo homologado é considerado sentença condenatória. $\S 9^{\circ} \mathrm{Se}$, por qualquer motivo, o acordo não for homologado, será ele desentranhado dos autos, ficando as partes proibidas de fazer quaisquer referências aos termos e condições então pactuados, tampouco o juiz em qualquer ato decisório. $\S 10$. No caso de acusado reincidente ou havendo elementos probatórios que indiquem conduta criminal habitual, reiterada ou profissional, o acordo deverá incluir o cumprimento de parcela da pena em regime fechado, 
salvo se insignificantes as infrações penais pretéritas. § 11. A celebração do acordo exige a concordância de todas as partes, não sendo a falta de assentimento suprível por decisão judicial, e o Ministério Público ou o querelante poderão deixar de celebrar o acordo com base na gravidade e nas circunstâncias da infração penal. (Grifo nosso).

Como estímulo ao acordo, o projeto prevê possibilidade de redução da pena até a metade, com possibilidade de alteração do regime de pena e substituição da pena privativa de liberdade, segundo a gravidade do crime, as circunstâncias do caso, e a colaboração do acusado para a rápida solução do processo (art. 395-A, § $1^{\circ}$, II c.c. $\S 2^{\circ}$ ).

A proposta se diferencia substancialmente do projeto de novo Código de Processo Penal (PL n. 8.045/2010) por permitir uma discricionariedade maior ao órgão acusador.

No PL n. 8.045/2010, há previsão de um procedimento sumário, com aplicação imediata da pena a imputações de crimes cuja pena máxima não seja superior a oito anos (em princípio, que não ensejariam de pronto regime fechado). De acordo com esse projeto, a pena do acordo deveria ser fixada no mínimo da cominação legal, com possibilidade de redução de até $1 / 3$ (art. 283 , caput c.c. $\S \S 1^{\circ}$, I, e $3^{\circ}$ ).

$\mathrm{O}$ texto encampado pelo pacote anticrime foge dos modelos que vêm sendo adotados em países da Civil Law, como França, Itália e Espanha, e ignora advertências que têm sido suscitadas em solo norte-americano (DEVERS, 2011, p. 4).

$\mathrm{Se}$, como tem sido observado pela literatura especializada, a crítica ao plea bargaining reside na distorção e no desequilíbrio de forças reais entre acusação e acusado, parece salutar que a experiência brasileira principie com alguma cautela, notadamente para evitar mácula à sua própria legitimação, como se observou, por exemplo, na exitosa, ainda que parcialmente controversa, experiência das delações premiadas praticadas durante a chamada operação Lava Jato.

Com efeito, vários atos processuais, como o cumprimento de mandados de busca com determinação de colheita imediata do depoimento do investigado, sob pena de condução coercitiva, ou, ainda, a profusão de prisões provisórias, foram objeto de questionamento por poderem ser vistos como instrumento de pressão para adesão dos atingidos a colaborações premiadas. ${ }^{29}$

O reconhecimento da invalidade das operações ou da violação de garantias coloca em risco a estabilidade das condenações promovidas em primeiro grau

29 O Ministério Público Federal admitiu essa possibilidade, em parecer exarado nos autos do HC n. 502905046.2014.404.0000, impetrado no âmbito da operação Lava Jato. Disponível em: https://www.conjur.com. br/dl/lava-jato-parecer-mpf-prisao-forcar.pdf. Acesso em: 28 fev. 2019. Teoricamente, contudo, isso suscita argumentos contrários à validação desses acordos, como observa Badaró (2015). 
e levanta suspeitas sobre a idoneidade dos membros dos Tribunais, em um processo de deslegitimação perigoso. No caso das conduções coercitivas, o STF, no julgamento da ADPF n. 395, por seis votos a cinco, reconheceu a inconstitucionalidade da medida, mas declarou a validade dos atos praticados até então. ${ }^{30}$

No âmbito das colaborações premiadas, lacunas legislativas, falta de experiência acumulada acerca do instituto e o anseio por lhe conferir grande eficácia fizeram com que fossem firmados acordos com benefícios não previstos em lei, que, embora homologados pelos Tribunais, deixam dúvidas quanto à legitimidade da excessiva generosidade de alguns de seus termos, o que certamente merecerá reflexão para fins de aprimoramento no manejo de módulos negociais no âmbito do processo penal. ${ }^{31}$

Nesse sentido, a previsão do procedimento sumário contida no PL $n$. 8.045/2010 parece mais adequada e menos arriscada a condições de deslegitimação ulteriores, como, aliás, observa Lopes Jr. (2019).

Também chama a atenção o parágrafo 10, com a já criticada expressão conduta criminal habitual, não definida normativamente, e agora com a agravante de que se trata de condição para que o acordo preveja regime inicial fechado.

Finalmente, de se registrar que é alvissareira a previsão contida no $\S 7^{\circ}$ no sentido de que o juiz deverá recusar a homologação do acordo caso a "proposta de penas formulada pelas partes for manifestamente ilegal ou manifestamente desproporcional à infração ou se as provas existentes no processo forem manifestamente insuficientes para uma condenação criminal”.

Ainda que tal obrigação, a nosso ver, nem precisasse vir textualmente expressa no projeto, já que inerente à função jurisdicional de controle da legalidade e legitimidade do processo penal, a redação do dispositivo sublinha salvaguardas que entendemos fundamentais para o adequado manejo de acordos no nosso sistema penal, sobretudo como mecanismos para se evitar que pessoas inocentes sejam levadas a aceitar ajustes em processos que careçam de um mínimo de lastro probatório contra si.

30 Não houve, ainda, publicação do acórdão, mas da análise da decisão monocrática do relator, Min. Gilmar Mendes, vê-se o reconhecimento da condução coercitiva como prática recorrente. Apenas na operação Lava Jato, segundo o relator, foram realizadas 222 conduções coercitivas dessa maneira. Disponível em: http:// portal.stf.jus.br/processos/downloadPeca.asp?id=15341445391\&ext=.pdf. Acesso em: 28 fev. 2019.

31 Segundo Rosa, o Judiciário é colocado "contra a parede", pressionado a homologar colaborações firmadas em descompasso com a lei (BRASIL, 2017, p. 150). Questionando a legitimidade de acordos realizados no âmbito da Lava Jato, Bottino do Amaral analisa os ajustes firmados entre o Ministério Público Federal e os investigados Paulo Roberto Costa, Alberto Youssef e Pedro José Barusco Filho, destacando os seguintes benefícios não previstos em lei constantes dos respectivos instrumentos: fixação de prazo máximo de prisão, independentemente das penas cominadas em sentença; limitação do tempo de prisão cautelar a 30 dias; cumprimento de pena em regime aberto; garantia de liberação de imóveis em favor de parentes, sem perquirição sobre sua possível origem ilícita; preservação de bens destinados ao pagamento de multa compensatória (quatro imóveis e um terreno) (AMARAL, 2016). 
5. Desafios para o uso republicano do instituto

Considerando que o processo penal tem uma função de garantia de direitos individuais (ônus de observância da ampla defesa e contraditório em favor do acusado) e instrumental ao adequado exercício da competência estatal de apurar a materialidade e autoria de crimes (com a punição dos respectivos responsáveis), a implantação/ alargamento de técnicas de solução negocial de pretensões de tal índole deve se cercar de cuidados para que tanto se dê para aprimoramento do nosso sistema de justiça (e não como uma via irrefletida de simplesmente se buscar o desafogamento de varas judiciais a todo custo).

Logo, deve-se pensar em um desenho institucional para o plea bargaining que estimule ao juiz, ao promotor e ao defensor uma atuação proativa e atenta para com os direitos do acusado e o propósito da jurisdição neste âmbito, de modo que a prerrogativa ministerial de propor o acordo e do réu de aceitá-lo não levem a distorções que apenas agravem críticas comumente feitas à aplicação da lei penal entre nós (como a de prestigiar o encarceramento como desfecho de tal atividade, consequência que recai normalmente apenas sobre pessoas de menor poder aquisitivo ${ }^{32}$ ).

Um primeiro passo nessa direção seria o estabelecimento de uma política clara e transparente para aplicação do instituto pelo Ministério Público, o que pressupõe um diagnóstico preciso dos desafios hoje existentes para que a jurisdição criminal, enquanto função estatal preordenada, em última instância, a desestimular a prática de delitos, cumpra sua razão de ser.

Ainda mais em tempos de big data, é chegada a hora de haver um levantamento minucioso de dados sobre nossa população carcerária, sobre os crimes mais recorrentes, suas causas, resposta recebida pelo sistema de justiça e, quando o caso, reincidência dos envolvidos.

Apenas refletindo sobre tais informações e dialogando com as esferas de governo competentes para a adoção de medidas capazes de prevenir crimes cuja origem esteja preponderantemente relacionada à pobreza e à drogadição, por exemplo, é que será possível ao órgão acusador estabelecer institucionalmente diretrizes acertadas tanto quanto às hipóteses em que caiba a propositura de acordos como no que se refere ao seu conteúdo (que inclusive pode envolver, quando tanto for conveniente, encaminhamento do acusado

\footnotetext{
32 Risco que não pode ser ignorado com a ampliação do uso de acordos em nosso sistema penal, como nos alertam estudos conduzidos pelo Departamento de Justiça norte-americano, os quais indicam que o excesso de discricionariedade dos órgãos acusatórios produzem reflexos na forma de punição mais acentuada da população negra. Nesse sentido, ver: Becker Jr. (1988, p. 2).
} 
a centros de acompanhamento psicossocial, psiquiátrico ou de apoio assistencial, como medidas de apoio à reorganização da vida do indivíduo infrator).

A concessão de maior poder ao Ministério Público quanto ao desfecho da ação penal deve, a nosso ver, ser proporcional ao dever de prestação de contas acerca dos resultados de sua atuação (cuja métrica adequada vai além do número de casos resolvidos pela via concertada, devendo necessariamente passar pela eficiência das medidas propostas para evitar reincidência, para recompor os bens jurídicos lesados ${ }^{33}$ e para tutela do devido processo legal substancial, o que envolve, em boa medida, a garantia do próprio direito de defesa).

Ao lado do Ministério Público, o incremento do uso de acordos na seara penal também exige do juiz e do defensor posturas condizentes com o papel a ser desempenhado por tais atores na nova realidade.

Ao defensor, cabe estar bem aparelhado e (in)formado, para o que certamente representou um enorme avanço em nosso sistema a progressiva implantação das Defensorias Públicas no que se refere à tutela dos réus hipossuficientes (já que para o público capaz de pagar honorários expressivos não há dúvidas de que o mercado brasileiro já possui profissionais extremamente habilitados para sua representação em juízo).

Se há receio quanto à possibilidade de pessoas serem induzidas a aceitar acordos que não lhes sejam favoráveis, este deve ser dirimido não só por uma atuação responsável do órgão acusador como pela performance intransigente da Defesa na salvaguarda dos melhores interesses dos seus assistidos, assegurando que sua adesão à oferta do promotor seja consentida, informada e em termos proporcionais.

Por outro lado, e não menos importante, vem a função do juiz como vigilante das tratativas entabuladas entre acusação e defesa, a garantir que estas sejam compatíveis com fatos objeto da apuração e com os elementos até então existentes contra o acusado, que sob nenhuma hipótese deve ser induzido a aceitar medida restritiva de sua liberdade em situações em que haja remota chance de sua condenação em juízo em decorrência do material probatório que o vincule ao cometimento de uma infração.

Um último ponto digno de nota quanto aos desafios a serem superados para o manejo republicano do plea bargaining entre nós é, ao lado da sua motivação suficiente no dia a dia do seu emprego pelas autoridades competentes, a preocupação com seu uso isonômico, de modo que para indivíduos em situações equivalentes seja garantido tratamento análogo, justificando-se, sempre, o porquê de eventual discriminação. ${ }^{34}$

33 Importante reflexão sobre a necessidade de uma maior fundamentação e coordenação na atuação do Ministério Público em torno de metas institucionais construídas junto com a sociedade pode ser encontrada em Ribeiro (2015, p. 158 et seq.).

34 Esse talvez seja hoje um dos temas mais desafiadores quando se analisa o incremento da consensualidade no exercício da função pública. Em ensaio recente, Tiago Cripa Alvim (2019), comentando o art. 27 da LINDB, 
6. Audiência de custódia e plea bargaining - perspectivas de maior eficiência na jurisdição criminal

Um bom termômetro para o uso dos acordos em nosso sistema será, a nosso ver, seu manejo nas audiências de custódia.

Por ocasião dessas oitivas, considerando que nelas o indivíduo é apresentado preso por ter sido encontrado em situação de flagrância e tem direito ao assessoramento prévio por advogado ou Defensor Público (Resolução CNJ n. 213/2015, art. $6^{\circ}$ ), afiguram-se reduzidas as chances de, reconhecida a licitude da prisão, induzir-se um terceiro inocente à aceitação de um acordo injusto apenas em razão do receio de sofrer um processo arbitrário.

Logo, em um contexto como o descrito, a introdução de módulos convencionais que permitam ao indivíduo, devidamente assessorado por seu defensor, confessar a imputação que lhe é feita e receber desde logo uma resposta do Estado pelo ocorrido, mais favorável do que aquela que seria possível ao fim do processo penal respectivo, pode implicar vantagem para todo o sistema de justiça.

Para tanto, contudo, é preciso reconfigurar o modelo das audiências de custódia, compreendendo-se que além da necessidade do prévio assessoramento por Defensor Público ou advogado, passe a haver a possibilidade de confissão do delito, inquirição hoje incompatível com a vedação do art. $8^{\circ}$, inciso VIII, da Resolução CNJ n. $213 / 2015$.

Em sendo superado o referido óbice, há que se diferenciar entre a possibilidade de aplicação do acordo de não persecução penal e o acordo para aplicação imediata da pena, que reclama a propositura prévia de denúncia.

Para a primeira hipótese, bastaria a modificação dos termos regulatórios da audiência de custódia.

Para a segunda, entretanto, é preciso avançar na consensualidade, já que a defesa teria de abdicar não só da dilação probatória no curso do processo, mas também da fase inquisitorial, em suposto desfavor de um cliente que sequer indiciado está.

Por isso, a aplicabilidade do instituto teria de ser restrita às hipóteses em que os elementos materiais já viabilizem o oferecimento de denúncia ou às hipóteses em que a própria defesa tome a iniciativa de propor o acordo, caso em que o Ministério Público teria a discricionariedade de aceitá-lo, ou não.

Com isso, atribuir-se-ia novo papel ao acusado e seu Defensor que, antevendo as possibilidades de investigação, sugeririam acordo em que se formalizasse a

lançou algumas luzes sobre o assunto. 
imputação e a assunção de culpa, com aplicação da pena nos termos da proposta prevista pelo projeto de reforma do Código de Processo Penal.

Como a iniciativa do acordo, nesse caso particular, é carreada à Defesa, não se vislumbra risco relevante à espontaneidade do ajuste por parte do seu proponente, restando à Acusação e ao juiz valorar a validade ou não da assunção de culpa que lhes é apresentada.

\section{Conclusão}

O projeto "anticrime" enviado pelo Ministro da Justiça ao Congresso Nacional padece de algumas imprecisões técnicas, de inconsistências terminológicas e de algum açodamento no trato das questões, mas tem o mérito de trazer à baila a necessidade de reformular o sistema processual acusatório, por meio da introdução de elementos de consensualidade que podem, em um contexto de elevada litigiosidade penal, trazer racionalidade e eficiência ao sistema de justiça.

A ideia do plea bargaining, em si, pode favorecer a evolução do sistema de aplicação de penas, na medida em que a consensualidade que orienta sua idealização favorece tanto ao Estado, que reduz custos, como ao acusado, que tem condições de obter reprimenda penal menos severa em razão de sua colaboração.

Todavia, não se pode menosprezar importantes riscos de distorção no manejo do instituto, como a possibilidade de incremento da seletividade do sistema punitivo e correlato deficit legitimatório do Direito Penal.

Nesse sentido, a proposta enviada ao Congresso suscita críticas, já que ignora estudos existentes sobre a experiência norte-americana e projetos mais debatidos já em trâmite (PL n. 8.045/2010 e 10.372/2018).

Além disso, ousou pouco, ao deixar de tratar da possibilidade de realização do acordo em audiências de custódia e ao não disciplinar de forma mais contundente as hipóteses de sanção pelo descumprimento do acordo.

Equilibrar o interesse no incremento da eficiência responsiva do sistema punitivo, que exsurge como um dos pilares legitimatórios da estrutura de dominação contemporânea do Estado, com os valores liberais de garantia individual é tarefa difícil, pois as aspirações em tensão são quase antagônicas.

Acreditamos, porém, que o plea bargaining, bem regulamentado, possa contribuir para melhor funcionamento do sistema jurídico-penal. Dessa forma, espera-se que o Congresso Nacional tenha sensibilidade para discutir o tema à exaustão e aprimorar o projeto encaminhado, viabilizando a inserção desses institutos de forma adequada em nosso ordenamento. 
A tarefa, tal como enunciada, é de grande envergadura e, para lograr êxito, exigirá o envolvimento do Estado (e sociedade) como um todo, e não só dos seus atores no processo penal.

São Paulo, 17 de abril de 2019.

\section{Referências}

ALSCHULER, Albert W. Plea bargaining and its history. Columbia Law Review, New York, v. 79, n. 1, p. 1-43, Jan. 1979.

ALVIM, Tiago Cripa. O lugar da isonomia entre compensações e compromissos processuais. In: CUNHA FILHO, Alexandre Jorge Carneiro da; ISSA, Rafael Hamze; SCHWIND, Rafael Wallbach. (coord.). Lei de introdução às normas do direito brasileiro: anotada. São Paulo, Quartier Latin, 2019. v. 2, p. 389-400.

AMARAL, Thiago Bottino do. Colaboração premiada e incentivos à cooperação no processo penal: uma análise crítica dos acordos firmados na "Operação Lava Jato". Revista Brasileira de Ciências Criminais, São Paulo, n. 122, p. 359-390, set./out. 2016.

ANUÁRIO BRASILEIRO DE SEGURANÇA PÚBLICA. São Paulo: Fórum Brasileiro de Segurança Pública, ano 10, 2016. ISSN 1983-7364. Disponível em: http:/www.forumseguranca. org.br/storage/10_anuario_site_18-11-2016-retificado.pdf. Acesso em: 25 fev. 2019.

BADARÓ, Gustavo Henrique Righi Ivahy. Quem está preso pode delatar? Ainda sobre a delação premiada e o requisito da voluntariedade. Jota, São Paulo, 23 jun. 2015. Disponível em: https:// www.jota.info/opiniao-e-analise/artigos/quem-esta-preso-pode-delatar-23062015. Acesso em: 1 mar. 2019.

BANCO MUNDIAL. Fazendo com que a justiça conte: medindo e aprimorando o desempenho do Judiciário no Brasil. Relatório n. 32789-BR, de 30 de dezembro de 2004. Disponível em: http:// documents.worldbank.org/curated/pt/927921468769735592/pdf/327890PORTUGUE10Que0A0Ju stica0Conte.pdf. Acesso em: 14 set. 2018.

BECKER JR., Loftus Eugene. Plea bargaining and the Supreme Court. Loyola of Los Angeles Law Review, Los Angeles, v. 21, n. 3, p. 757-842, April 1998.

BITENCOURT, Cesar Roberto. Manual de direito penal. 7. ed., rev. e atual. São Paulo: Saraiva, 2002. v. 1.

BRASIL. Congresso Nacional. Comissão Parlamentar Mista de Inquérito destinada a investigar supostas irregularidades envolvendo as empresas JBS e J\&F em operações realizadas com o BNDES e BNDES-PAR ocorridas entre os anos de 2007 e 2016, que geraram prejuízos ao interesse público; investigar os procedimentos do acordo de colaboração premiada celebrado entre o Ministério Público Federal e os acionistas das empresas JBS e J\&F. Relatório final. Brasília, DF, 12 
de dezembro de 2017. Disponível em: https://static.poder360.com.br/2017/12/Relato\%CC\%81rioFinal-CPI-da-JBS.pdf. Acesso em: 17 set. 2018.

BRASIL. Supremo Tribunal Federal. ADPF n. 395. Portal do STF, Brasília, DF., 2016. Disponível em: http://portal.stf.jus.br/processos/detalhe.asp?incidente=4962368. Acesso em: 28 fev. 2019.

CARNEVALI RODRÍGUEZ, Raúl. Derecho penal como ultima ratio. Hacia una política criminal racional. Ius et Praxis, Talca, v. 14, n. 1, p. 13-48, 2008. Disponible em: https://scielo.conicyt.cl/ scielo.php?script=sci_arttext\&pid=S0718-00122008000100002\&lng=es\&nrm=iso. Acesso em: 4 jul. 2018.

CHEVALlIER, Jacques. O Estado pós-moderno. Tradução Marçal Justen Filho. Belo Horizonte: Fórum, 2009.

COHN, Gabriel. Weber, Frankfurt: teoria e pensamento social 1. Rio de Janeiro: Azougue Editorial, 2017.

CUNHA FILHO, Alexandre Jorge Carneiro da; ISSA, Rafael Hamze; SCHWIND, Rafael Wallbach. (coord.). Lei de introdução às normas do direito brasileiro. Anotada. São Paulo: Quartier Latin, 2019. v. 2.

DERVAN, Lucian E.; EDKINS, Vanessa A. The Innocence defendant's dilemma: an innovative empirical study of plea bargaining's innocence problem. Journal of Criminal Law and Criminology, Chicago, v. 103, n. 1, p. 1-48, 2013. Disponível em: https://scholarlycommons.law.northwestern. edu/cgi/viewcontent.cgi?article=1000\&context=jclc. Acesso em: 17 abr. 2019.

DEVERS, Lindsey. Research summary: plea and charge bargaining. Arlington: BJA, Jan. 2011. Disponível em: https://www.bja.gov/Publications/PleaBargainingResearchSummary.pdf. Acesso em: 26 fev. 2019.

ESQUIROL, Jorge L. O direito fracassado da América Latina. In: MACEDO JÚNIOR, Ronaldo Porto; BARBIERI, Catarina Helena Cortada (org.). Direito e interpretação: racionalidades e instituições. São Paulo: Saraiva, 2011. p. 439-503.

FARIA, José Eduardo Campos de Oliveira. O Estado e o direito depois da crise. 3. ed. ampl. e ainda não publicada. Lida em manuscrito. São Paulo: Saraiva, 2017.

GIFFORD, Donald G. Meaningful reform of plea bargaining: the control of prosecutorial discretion. University of Illinois Law Review, Champaign, n. 1, p. 37-97, 1983.

GIVATI, Yehonatan. The comparative law and economics of plea bargaining: theory and evidence. Cambridge, MA: Harvard Law School, July, 2011. Discussion paper n. 39. Disponível em: http:// www.law.harvard.edu/programs/olin_center/fellows_papers/pdf/Givati_39.pdf. Acesso em: 27 fev. 2019.

GRAU, Eros Roberto. Ensaio e discurso sobre a interpretaçã/aplicação do direito. São Paulo: Malheiros, 2002. 
HASSEMER, Winfried. Características e crises do moderno direito penal. Tradução Pablo Rodrigo Alflen da Silva. Revista Síntese de Direito Penal e Processual Penal, Porto Alegre, v. 3, n. 18, p. 144-157, fev./mar. 2003.

. Direito penal, defesa penal e Constituição. Lusíada, Lisboa, n. 4/5, p. 519-526, 2007. Disponível em: http://dspace.lis.ulusiada.pt/bitstream/11067/1214/1/LD_n4-5_28.pdf. Acesso em: 10 jul. 2018.

IPEA. Atlas da violência. São Paulo: Fórum Brasileiro de Segurança Pública, 2017. Disponível em: http://www.ipea.gov.br/portal/images/170602_atlas_da_violencia_2017.pdf. Acesso em: 25 fev. 2019.

JAKOBS, Günther. Direito penal do inimigo. In: JAKOBS, Günther; CANCIO MELIÁ, Manuel. Direito penal do inimigo: noções e críticas. Organização e tradução de André Luís Callegari e Nereu José Giacomolli. 2. ed. Porto Alegre, RS: Livraria do Advogado, 2007. p. 21-50.

Sociedad, norma y persona en una teoría de un derecho penal funcional. Trad. Manuel Cancio Meliá y Bernardo Feijoó Sánchez. Madri: Civitas Ediciones, 2000.

. Terroristas como pessoas no direito? Tradução de Luciano Gatti. Novos Estudos-CEBRAP, São Paulo, n. 83, p. 27-36, mar. 2009.

JOHNSTON, David. Breve história da justiça. Tradução Fernando Santos. São Paulo: Martins Fontes, 2018.

KISHAN, Hari. Darker side of plea bargaining: the worldwide scenario with future perspectives. International Journal of Advance Research and Development, Panchkula, v. 3, n. 6, p. 28-37, June 2018. Disponível em: https://www.ijarnd.com/manuscripts/v3i6/V3I6-1147.pdf. Acesso em: 27 fev. 2019.

LOPES JR., Aury Celso Lima. Adoção do plea bargaining no projeto "anticrime": remédio ou veneno? Revista Consultor Jurídico, São Paulo, fev. 2019. Disponível em: https://www.conjur.com. br/2019-fev-22/limite-penal-adocao-plea-bargaining-projeto-anticrimeremedio-ou-veneno. Acesso em: 1 mar. 2019.

MARRARA, Thiago. Acordos de leniência no processo administrativo brasileiro: modalidades, regime jurídico e problemas emergentes. Revista Digital de Direito Administrativo - RDDA, Ribeirão Preto, v. 2, n. 2, p. 509-527, 2015.

MEDAUAR, Odete. A processualidade no direito administrativo. 2. ed. rev. atual. e ampl. São Paulo: Revista dos Tribunais, 2008.

PALMA, Juliana Bonacorsi de. Sanção e acordo na administração pública. São Paulo: Malheiros, 2015. 
PIETRO SANCHÍS, Luís. Constitucionalismo e garantismo. In: MOREIRA, Eduardo Ribeiro; PUGLIESI, Marcio (coord.). 20 anos da Constituição brasileira. São Paulo: Saraiva, 2009. p. 377394.

PRADO, Luiz Regis. Tratado de direito penal brasileiro. São Paulo: Revista dos Tribunais, 2014. V. 3.

RIBEIRO, Carlos Vinicius Alves. Ministério Público - funções extrajudiciais: histórico, natureza jurídica, discricionariedade, limites e controle. Belo Horizonte: Fórum, 2015.

SANTOS, Boaventura de Sousa. A gramática do tempo: para uma nova cultura política. 3. ed. São Paulo: Cortêz, 2010.

SANTOS, Ivanaldo. Da gênese à crise do Estado de bem-estar. Cronos, Natal, v. 5/6, n. 1/2, p. 289308, jan./dez. 2004/2005.

SANTOS, Wanderley Guilherme dos. Razões da desordem. 3. ed. Rio de Janeiro: Rocco, 1994.

SARLET, Ingo Wolfgang. A eficácia dos direitos fundamentais. 4. ed. rev., atual. e ampl. Porto Alegre: Livraria do Advogado, 2004.

SHEPPARD, Lee. Disclosure to the guilty pleading defendant: Brady v. Maryland and the Brady trilogy. Journal of Criminal Law and Criminology, Chicago, v. 72, n. 1, spring 1981.

SILVA SÁNCHES, Jesús-María. A expansão do direito penal: aspectos da política criminal nas sociedades pós-industriais. Tradução da $2^{a}$ edição espanhola, por Luiz Otavio de Oliveira Rocha. São Paulo: Revista dos Tribunais, 2002.

WACQUANT, Loïc. A tempestade global da lei e ordem: sobre punição e neoliberalismo. Revista de Sociologia Política, Curitiba, v. 20, n. 41, p. 7-20, fev. 2012. Disponível em: https://revistas.ufpr. br/rsp/article/view/31766/20292. Acesso em: 10 jul. 2018.

ZAFFARONI, Eugenio Raúl; PIERANGELI, José Henrique. Manual de direito penal brasileiro. 12. ed. São Paulo: Revista dos Tribunais, 2018. 
